\title{
Indole-3-Acetic Acid Improves Postharvest Biological Control of Blue Mold Rot of Apple by Cryptococcus laurentii
}

\author{
Ting Yu, Jishuang Chen, Huangping Lu, and Xiaodong Zheng
}

First, third, and fourth authors: Department of Food Science and Nutrition, Zhejiang University, Hangzhou, 310029, People's Republic of China; and second author: Institute of Bioengineering, Zhejiang Sci-Tech University, Hangzhou, 310018, People's Republic of China. Accepted for publication 9 October 2008.

\section{ABSTRACT}

Yu, T., Chen, J., Lu, H., and Zheng, X. 2009. Indole-3-acetic acid improves postharvest biological control of blue mold rot of apple by Cryptococcus laurentii. Phytopathology 99:258-264.

Cryptococcus laurentii is a well-known postharvest biocontrol yeast; however, it cannot provide satisfactory levels of decay control when used alone. Here, we evaluated the effects of indole-3-acetic acid (IAA), a plant growth regulator, on the biocontrol efficacy of the yeast antagonist C. laurentii against blue mold rot caused by Penicillium expansum in apple fruit. Results showed that the addition of IAA at $20 \mu \mathrm{g} / \mathrm{ml}$ to suspensions of $C$. laurentii greatly enhanced inhibition of mold rot in apple wounds compared with that observed with $C$. laurentii alone. The addition of IAA at $20 \mu \mathrm{g} / \mathrm{ml}$ or lower did not influence the population growth of $C$. laurentii in wounds, but adverse effects were seen on $C$. laurentii when the concentration of IAA was increased to $200 \mu \mathrm{g} / \mathrm{ml}$ or above in vitro and in vivo. $P$. expansum infection in apple wounds was not inhibited when the pathogen was inoculated into the fruit wounds within $2 \mathrm{~h}$ after application of IAA; however, infection was reduced when inoculated more than $12 \mathrm{~h}$ after IAA application. Treatment of wounds with IAA at $20 \mu \mathrm{g} / \mathrm{ml} 24 \mathrm{~h}$ before pathogen inoculation resulted in significant inhibition of $P$. expansum spore germination and host infection. Application of IAA at $20 \mu \mathrm{g} / \mathrm{ml}$ also reduced $P$. expansum infection when it was applied $48 \mathrm{~h}$ before pathogen inoculation in the intact fruit. Thus, IAA could reinforce the biocontrol efficacy of $C$. laurentii in inhibiting blue mold of apple fruit by induction of the natural resistance of the fruit.
Blue mold rot, caused by the wound-invading necrotrophic fungus Penicillium expansum, is a major postharvest disease of apple fruit $(1,16)$. Given limited applications of synthetic fungicides, the effective and safe nonfungicide approaches to control postharvest decay have been continually explored in recent years (16). Proposed nonfungicide approaches include the following: (i) biological methods, such as using antagonistic microorganisms, natural and safe bioactive compounds, and induced resistance; and (ii) physical methods, such as cold storage, controlled or modified atmosphere storage, heat treatment, ultraviolet light irradiation, and ozone. However, none of these methods, when used alone, provide satisfactory levels of decay control compared with using synthetic fungicides. Therefore, a current principal strategy for nonfungicide control of fruit decay has been to develop an integrated management strategy that combines various biological and physical means $(8,10,11,16,28)$.

Strains of the yeast Cryptococcus laurentii are widely studied for their potential in biological control. They have been found to have strong antagonistic activity against postharvest pathogens of apple fruit when used alone or in combination with certain additives, including calcium chloride, chitosan, gibberellic acid, food additives, low doses of fungicides, salicylic acid, and sodium bicarbonate $(8,17,18,26,33-35)$.

Indole-3-acetic acid (IAA) is the most important auxin of higher plants (4), contributing to the processes of ripening and senescence of harvested produce $(3,6,19)$ and pathogen defense mechanisms in Arabidopsis thaliana and tomato plants $(20,21)$. Recent evidence indicates IAA displays in vitro antifungal activity against Ustilago maydis and Saccharomyces cerevisiae (25), and in vivo activity against Gibberella pulicaris and

Corresponding author: X. Zheng; E-mail address: xdzheng@ @ zju.edu.cn

doi:10.1094/PHYTO-99-3-0258

(c) 2009 The American Phytopathological Society
Phytophthora infestans in potato $(22,29)$. However, little information is available for evaluating the effects of IAA on the fungal disease of harvested fruit. We recently observed that IAA could enhance the biocontrol efficacy of $C$. laurentii against $P$. expansum and Botrytis cinerea in pear fruit, but the mechanism by which IAA enhanced the biocontrol efficacy was not made clear (36).

This study was conducted to evaluate (i) the efficacy of $C$. laurentii with IAA in controlling blue mold rot in apple fruit; (ii) the effects of IAA on induction of the resistance to blue mold rot in apple fruit; (iii) the antifungal activity of IAA on the spore germination of $P$. expansum in vivo and the spore survival of $P$. expansum in vitro; and (iv) the influence of IAA on the population and the survival of $C$. laurentii in vivo and in vitro.

\section{MATERIALS AND METHODS}

Fruit material, antagonist, and fungal pathogen. Fuji apple fruit (Malus domestica Borkh.) was harvested at commercial maturity and those having uniformity in size and ripeness and lack of any apparent injuries or infection were selected. Fruit samples were surface-disinfected with sodium hypochlorite at $0.1 \%$ (vol/vol) for $1 \mathrm{~min}$, rinsed with tap water, and allowed to air dry at room temperature $\left(20^{\circ} \mathrm{C}\right)$.

The yeast antagonist $C$. laurentii (Kufferath) Skinner strain zju10 was originally isolated from the surface of pear fruit and identified by VITEK 32 Automicrobic System (bioMerieux Company, Marcy l'Etoile, France) and streaked on nutrient yeast dextrose agar (NYDA) medium (containing $8 \mathrm{~g}$ of nutrient broth, $5 \mathrm{~g}$ of yeast extract, $10 \mathrm{~g}$ of glucose, and $20 \mathrm{~g}$ of agar in 1 liter of distilled water) and incubated at $28^{\circ} \mathrm{C}$ for $48 \mathrm{~h}$. The yeast cells were cultured in nutrient yeast dextrose broth (NYDB) and incubated for $24 \mathrm{~h}$ at $28^{\circ} \mathrm{C}$ on a gyratory shaker at $200 \mathrm{rpm}$. The yeast cells were harvested by centrifuging at 3,000 $\times g$ for $10 \mathrm{~min}$ and washed twice with sterile distilled water. The concentration of yeast cells was counted with a hemacytometer. 
The pathogen $P$. expansum strain PE-z was originally isolated from apple fruit showing typical blue rot and was cultured on potato dextrose agar (PDA) medium (containing the extract from $200 \mathrm{~g}$ of boiled potato, $20 \mathrm{~g}$ of glucose, and $20 \mathrm{~g}$ of agar in 1 liter of distilled water) at $28^{\circ} \mathrm{C}$ in the dark. Spore suspension was prepared by flooding 7-day-old sporulating cultures of $P$. expansum with sterile distilled water. The spore concentration was counted with a hemacytometer.

Control of blue mold rot by $\boldsymbol{C}$. laurentii with IAA. IAA was purchased from local producers (Sinopharm Chemical Reagent Co., Ltd., Shanghai, China) and prepared by dissolving absolute alcohol and adjusting the $\mathrm{pH}$ to 6 with 1 mol liter $^{-1} \mathrm{NaOH}$, followed by filter sterilization $(0.45 \mu \mathrm{m})$ for immediate use. To conduct postharvest disease assays, the surfaces of apples were wounded at four different sites with a sterile cork borer (approximately $5 \mathrm{~mm}$ diameter and $3 \mathrm{~mm}$ deep) and treated with $30 \mu \mathrm{l}$ of a solution of the following: (i) C. laurentii suspension $\left(1 \times 10^{8}\right.$ cells $\left./ \mathrm{ml}\right)$; (ii) IAA at $2,20,200$, or $2,000 \mu \mathrm{g} / \mathrm{ml}$; and (iii) C. laurentii suspension $\left(1 \times 10^{8}\right.$ cells $\left./ \mathrm{ml}\right)$ with IAA at final concentrations of 2, 20,200, or 2,000 $\mu \mathrm{g} / \mathrm{ml}$. After $2 \mathrm{~h}$, a solution of $30 \mu \mathrm{l}$ of $P$. expansum spore suspension $\left(1 \times 10^{4} \mathrm{spores} / \mathrm{ml}\right)$ was inoculated onto each wound. Wounds treated with sterile distilled water and with $P$. expansum spore suspension served as the inoculated positive disease control. In each experiment, wounds treated with either sterile distilled water, biocontrol yeast suspension, or IAA solutions without pathogen inoculation were used as negative controls. For all experiments, negative controls did not exhibit disease symptoms. After air drying, the apples were stored in trays covered with plastic film to maintain a high relative humidity at $20^{\circ} \mathrm{C}$. The number of infected wounds and their lesion diameters were examined daily. Fruit were scored for disease incidence, based on first visual appearance of rot, and disease severity, based on lesion diameter as determined by average length of perpendicular measurements. Each experiment consisted of four replicates per treatment, consisting of 24 fruit samples per replicate, totaling 96 wound sites.

Growth of $C$. laurentii in the presence of IAA. In vitro. $C$. laurentii was cultured on NYDB amended with filter-sterilized IAA at $0,0.1,1,10,100$, or $1,000 \mu \mathrm{g} / \mathrm{ml}$. Shake-flask cultures were started with yeast cells (approximately $5 \times 10^{4}$ cells $/ \mathrm{ml}$ ) and incubated on a rotary shaker $(200 \mathrm{rpm})$ at $28^{\circ} \mathrm{C}$. Samples were collected after $24 \mathrm{~h}$, and the cell concentration was counted with a hemacytometer after diluting with sterile distilled water if necessary. There were three replicates per treatment and three flasks per replicate.

In vivo. Fruit samples were wounded at five different sites with a sterile cork borer, and each wound (apart $2 \mathrm{~cm}$ each) on one fruit was treated with each of the different IAA concentrations $(0$, $2,20,200$, or $2,000 \mu \mathrm{g} / \mathrm{ml})$ and $C$. laurentii suspension $\left(2 \times 10^{7}\right.$ cells/ml, $30 \mu \mathrm{l})$. After air drying, the samples were stored in trays covered with plastic film to maintain a high relative humidity at $20^{\circ} \mathrm{C}$. Tissues were removed at the wound site of treated fruit with a sterile cork borer ( $1 \mathrm{~cm}$ diameter by $1 \mathrm{~cm}$ deep) at $0,12,24,48$, 72 , and $96 \mathrm{~h}$ and ground with a mortar and pestle in $10 \mathrm{ml}$ of sterile water. Yeast cells were counted with a hemacytometer. There were three replicates per treatment and six fruit samples per replicate for each time point. Experiments were conducted at least twice.

Survival of $C$. laurentii or $P$. expansum in the presence of IAA. Equal amount of $C$. laurentii cells or $P$. expansum spores were incubated in solutions of IAA at various concentrations $(0$, $1,10,100$, or $1,000 \mu \mathrm{g} / \mathrm{ml}$ ) in a final volume of $1 \mathrm{ml}$ for $60 \mathrm{~s}$, centrifuged, and resuspended in water to remove the IAA solution prior to plating on the agar medium. Then, $100 \mu \mathrm{l}$ of each suspension was plated on NYDA or PDA. After 36 or $72 \mathrm{~h}$ of incubation at $28^{\circ} \mathrm{C}$, the yeast colonies or the fungal colonies were counted and calculated as the mean value of colony forming units $(\mathrm{CFU})$ per plate. There were three replicates per treatment and four plates per replicate. All treatments were arranged in a randomized complete block design and conducted at least twice.

$\boldsymbol{P}$. expansum spore germination in vivo. Two of the four wounded sites on one apple fruit were treated with $30 \mu \mathrm{l}$ of sterile distilled water (the control), and the other two wounds were treated with $30 \mu \mathrm{l}$ of a solution of IAA at $20 \mu \mathrm{g} / \mathrm{ml}$ in a randomized complete block design. After 2 or $24 \mathrm{~h}, 30 \mu \mathrm{l}$ of the $P$. expansum spore suspension $\left(1.5 \times 10^{7}\right.$ spores $\left./ \mathrm{ml}\right)$ was inoculated into each wound at each time point. Use of the high concentration was necessary in order to observe the spores by optical microscopy. After air drying, fruit samples were stored in trays covered with plastic film to maintain a high relative humidity at $20^{\circ} \mathrm{C}$. At equal $12 \mathrm{~h}$ postinoculation with pathogen for each time point, germinated spores of $P$. expansum were examined by an optical microscope. The number of germinated spores was divided by the total observed spores (at least 200 spores in each replicate, usually used multiple fields of view to reach 200 spores) and multiplied by 100 as the percent spore germination. There were three replicates per treatment, with each replicate consisting of nine fruit samples for each time point.

Effects of IAA on induction of apple fruit resistance in wounds. The surfaces of apples were wounded at six different sites and each of the wounds was treated with $30 \mu \mathrm{l}$ of filtersterilized IAA at $2,20,50,100$, and $200 \mu \mathrm{g} / \mathrm{ml}$ or with $30 \mu \mathrm{l}$ of distilled water (the control) on one fruit in a randomized complete block design, followed by inoculation of $30 \mu \mathrm{l}$ of the $P$. expansum spore suspension $\left(1 \times 10^{5}\right.$ spores $\left./ \mathrm{ml}\right)$ after $24 \mathrm{~h}$. There were three replicates per treatment and 12 fruit samples per replicate.

In another experiment, apples were wounded at four different sites and two of the wounds were treated with $30 \mu \mathrm{l}$ of filtersterilized IAA at $20 \mu \mathrm{g} / \mathrm{ml}$ or with $30 \mu \mathrm{l}$ of distilled water (the control) on one fruit in a randomized complete block design, followed by the inoculation of $30 \mu \mathrm{l}$ of the $P$. expansum spore suspension at $1 \times 10^{6}$ spores $/ \mathrm{ml}$ or at $1 \times 10^{2}$ spores $/ \mathrm{ml}$ onto each wound after 2, 12, and $24 \mathrm{~h}$. There were 12 fruit samples per replicate and three replicates per treatment for each time point.

Then, all of the above samples were stored in trays covered with plastic film to maintain a high relative humidity at $20^{\circ} \mathrm{C}$. The number of infected fruit and their lesion diameters were examined daily and recorded after equal time of incubation for each timing treatment. The percent inhibition (\%) for each treatment was calculated by comparison with the water control: Inhibition $(\%)=$ [(average lesion diameter of infected wounds in the control • average lesion diameter of infected wounds in the treatment)/ average lesion diameter of infected wounds in the control] $\times 100$.

The correlation of the efficacy of the induced resistance in inhibiting the average lesion diameter by IAA from 2 to $200 \mu \mathrm{g} / \mathrm{ml}$ and the incubation time and of the efficacy of the induced resistance by IAA from 2 to $200 \mu \mathrm{g} / \mathrm{ml}$ and the efficacy of $C$. laurentii with IAA at the corresponding concentration in inhibiting the average lesion diameter were analyzed by the Pearson correlation test (2-tailed) in Statistical Program (SPSS/PC version II.x).

Effects of IAA on induction of resistance in intact apple fruit. The intact fruit samples were dipped in IAA $(20 \mu \mathrm{g} / \mathrm{ml})$ solution for $20 \mathrm{~min}$ or in the distilled water for $20 \mathrm{~min}$ as the control. After $0,24,48,72,96$, and $120 \mathrm{~h}$, one of six sets of the treated fruit was wounded ( $5 \mathrm{~mm}$ diameter and $3 \mathrm{~mm}$ deep) at four different sites on the fruit surface and inoculated with $30 \mu \mathrm{l}$ of $P$. expansum spore suspension $\left(1 \times 10^{4}\right.$ spores $\left./ \mathrm{ml}\right)$. Then the fruit samples were stored in the enclosed plastic trays to maintain high humid conditions at $20^{\circ} \mathrm{C}$. The disease incidence was recorded on every fourth day after inoculation. The percentage of the rotted wounds ( $\%$ of control) was calculated as follows: the number of the average of rotted fruit obtained from each treatment was divided by the values of the control (pretreated with water and then inoculation with $P$. expansum for each time interval) and then multiplied by 100 . There were three replicates 
per treatment and 15 fruit samples (total of 60 wounds) per replicate for each time interval.

All treatments above were arranged in a randomized complete block design and conducted at least twice. Data are from one individual experiment and are representative of two independent experiments with similar results. The analysis of variance from Statistical Program (SPSS/PC version II.x) was performed on the data and the Duncan's multiple range test was used for means separation.

\section{RESULTS}

Inhibition of blue mold rot by $C$. laurentii with IAA. As shown in Figure 1, IAA at concentrations from 20 to $2,000 \mu \mathrm{g} / \mathrm{ml}$ did not directly inhibit blue mold infection in apple wounds $(P<$ $0.05)$. In contrast, application of the yeast $C$. laurentii inhibited

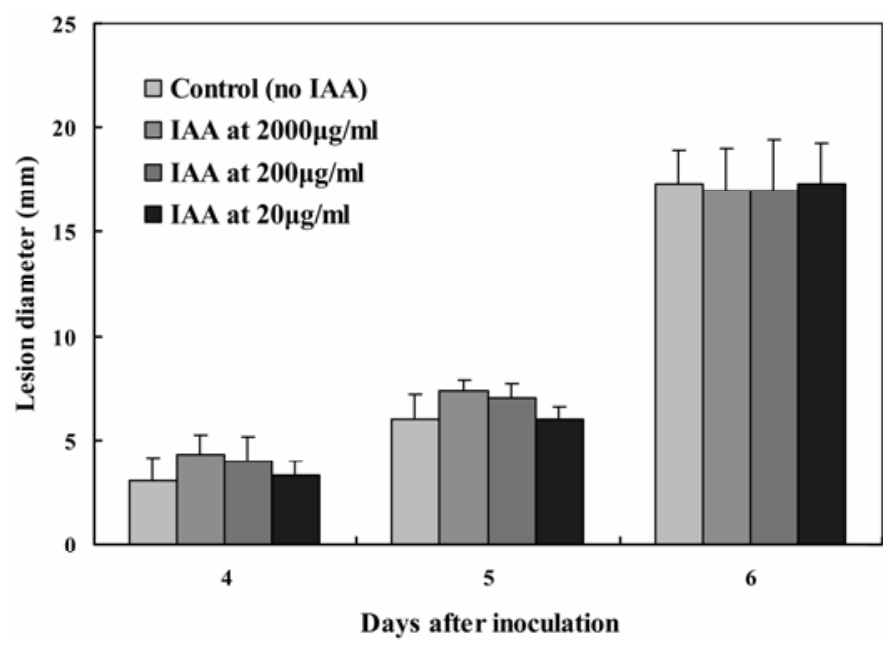

Fig. 1. Effects of indole-3-acetic acid on blue mold rot caused by Penicillium expansum $\left(10^{5}\right.$ spores $\left./ \mathrm{ml}\right)$ in apple and pear fruit. Values of lesion diameter represent the mean of four independent replicates and bars represent the standard errors. No significant differences $(P=0.05)$ were observed between treatments according to Duncan's multiple range test for each time point. both blue mold incidence and lesion diameter, especially during the early stages of an 8-day incubation period (Fig. 2). The incidence of disease and its average lesion diameter in the treatment by $C$. laurentii were 58.6 and $79.3 \%$ of those in the inoculated control on day $5(P<0.0001)$. However, the efficacy of $C$. laurentii decreased rapidly with incubation time. On day 8 , there was no difference in rot incidence between treatments with $C$. laurentii and that of the inoculated control $(P>0.05)$, although the mean value for lesion diameter in wounds treated with $C$. laurentii was lower than that in wounds of the inoculated control (77.1\% of the water control, $P<0.01$ ).

The addition of IAA at concentrations between 2 and $20 \mu \mathrm{g} / \mathrm{ml}$ to $C$. laurentii suspensions resulted in remarkably increased efficacy in inhibiting the blue mold disease compared with the treatment of $C$. laurentii alone between 5 and 8 days after inoculation (Fig. 2). Rot incidence in wounds treated with $C$. laurentii and IAA at $20 \mu \mathrm{g} / \mathrm{ml}$ was only $6.7 \%$ of the $C$. laurentii alone on day $5(P<0.0001)$. On day 7 , rot incidence and the lesion diameter in wounds treated with $C$. laurentii and IAA at $20 \mu \mathrm{g} / \mathrm{ml}$ were lower than with $C$. laurentii and IAA at $2 \mu \mathrm{g} / \mathrm{ml}(P<0.001$ for rot incidence and $P<0.05$ for lesion diameter). Treatments of C. laurentii with IAA at $200 \mu \mathrm{g} / \mathrm{ml}$ also enhanced the inhibition of blue mold incidence on day 5 and on day $6(P<0.01)$ compared with $C$. laurentii alone; however, this treatment was less effective than treatments with $C$. laurentii and IAA at 2 and $20 \mu \mathrm{g} / \mathrm{ml}(P<$ $0.01)$. In contrast to lower concentrations of IAA, a combination of $C$. laurentii with IAA at $2,000 \mu \mathrm{g} / \mathrm{ml}$ resulted in adverse effects on reduction of the $P$. expansum infection compared with the treatment with $C$. laurentii alone; the higher IAA concentration treatment resulted in disease incidence similar to the untreated disease control (Fig. 2).

Effect of IAA on the biocontrol yeast $C$. laurentii and the pathogen $\boldsymbol{P}$. expansum in vitro. In general, IAA exhibited adverse effects on both $C$. laurentii cells and $P$. expansum spores under in vitro conditions (Table 1). When $C$. laurentii was incubated in NYDB with the addition of IAA at high concentrations of 100 and $1,000 \mu \mathrm{g} / \mathrm{ml}$ for $24 \mathrm{~h}, C$. laurentii population levels did not increase above detectable levels of $5 \times 10^{4} \mathrm{CFU} / \mathrm{ml}$ $(P<0.05)$. Even at the lowest IAA concentration of $0.1 \mu \mathrm{g} / \mathrm{ml}$, growth of $C$. laurentii was significantly inhibited compared with the untreated control $(P<0.05)$.
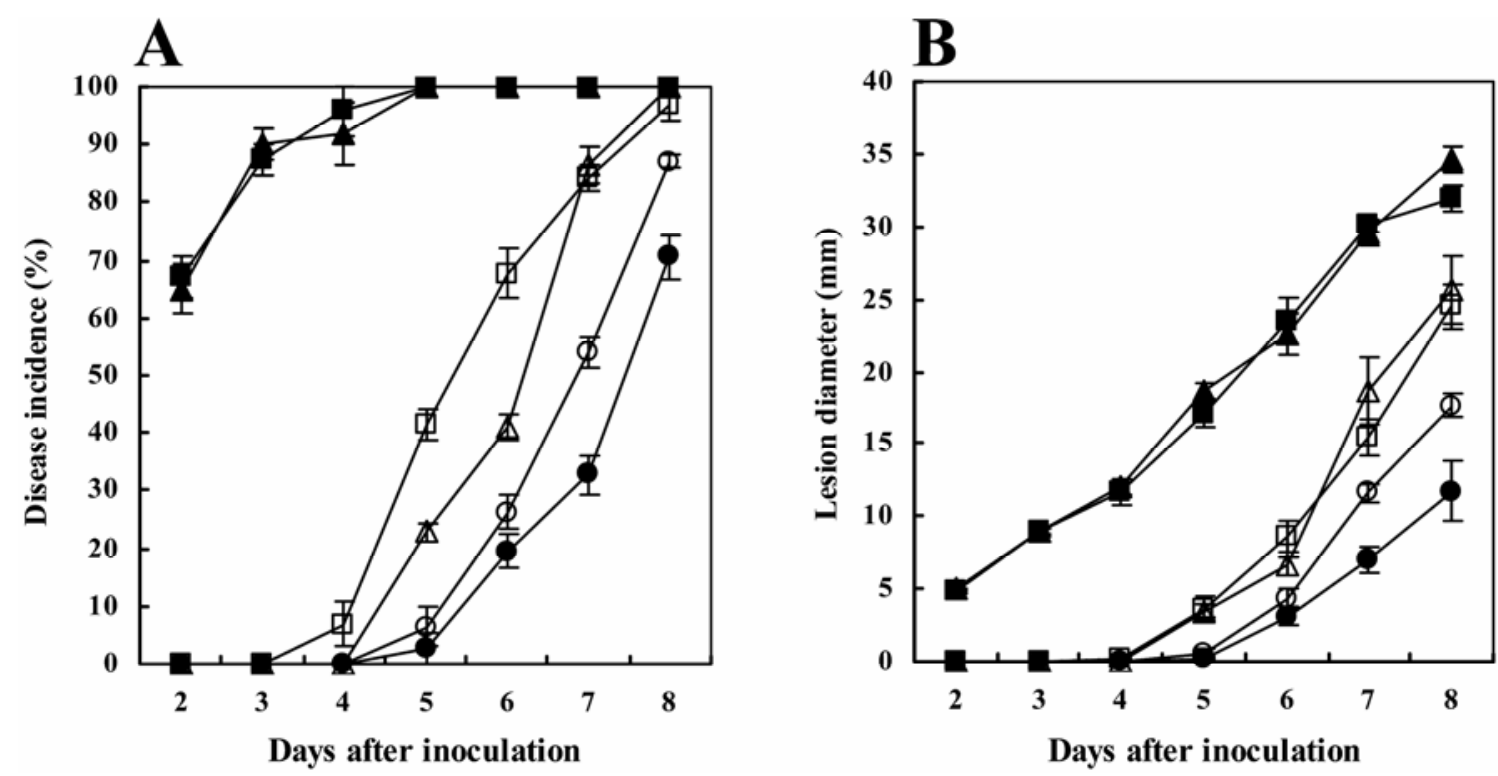

Fig. 2. Development of blue mold rot $\mathbf{A}$, incidence and $\mathbf{B}$, lesion diameter on apple fruit treated with Cryptococcus laurentii at $1 \times 10^{8}$ cells/ml $(\square)$ and indole-3acetic acid (IAA) at $2,000 \mu \mathrm{g} / \mathrm{ml}(\boldsymbol{\Lambda}), 200 \mu \mathrm{g} / \mathrm{ml}(\triangle), 20 \mu \mathrm{g} / \mathrm{ml}(\bullet)$, or $2 \mu \mathrm{g} / \mathrm{ml}(\bigcirc)$ followed by inoculation with Penicillium expansum at $1 \times 10^{4}$ spores $/ \mathrm{ml}$ within $2 \mathrm{~h}\left(20^{\circ} \mathrm{C}\right)$. The treatment with distilled water and inoculated with $P$. expansum served as the inoculated control ( $\left.\square\right)$. Values of rot incidence and lesion diameter represent the mean of four independent replicates and bars represent the standard errors. 
On the surface of the agar culture medium NYDA (Table 1), IAA between concentrations of 1 to $1,000 \mu \mathrm{g} / \mathrm{ml}$ also exhibited adverse effects on the growth of $C$. laurentii $(P<0.05)$. However, for the pathogen $P$. expansum, significant growth inhibition was shown only at the high concentration of $1,000 \mu \mathrm{g} / \mathrm{ml}$ IAA $(P<$ $0.05)$, whereas no differences were observed with IAA treatments between 0 and $100 \mu \mathrm{g} / \mathrm{ml}$ on PDA $(P>0.05)$.

Growth of the yeast antagonist in apple wounds. $C$. laurentii proliferated rapidly in apple wounds, especially during the first $24 \mathrm{~h}$ (Fig. 3). Growth was not influenced by the addition of IAA at concentrations of $20 \mu \mathrm{g} / \mathrm{ml}$ or lower during $96 \mathrm{~h}$ of incubation $(P>0.05)$. However, IAA concentrations at $200 \mu \mathrm{g} / \mathrm{ml}$ or above significantly inhibited the growth of yeast in apple wounds, especially during the first $48 \mathrm{~h}$ of incubation $(P<0.05)$. Furthermore, at $24 \mathrm{~h}, C$. laurentii populations incubated with IAA at the highest concentration of $2,000 \mu \mathrm{g} / \mathrm{ml}$ were reduced more than sevenfold compared with populations of the untreated control $(P<0.05)$. However, little difference was detected in the $C$. laurentii populations for all treatments after $72 \mathrm{~h}$ inoculation $(P>0.05)$.

Pathogen spore germination in apples wounds. When the time interval between IAA application and $P$. expansum spore inoculation onto fresh wounds was $2 \mathrm{~h}$, nearly $100 \%$ of spores germinated within $12 \mathrm{~h}$ after inoculation regardless of the presence or absence of IAA at $20 \mu \mathrm{g} / \mathrm{ml}$ (Fig. 4). In contrast, germination was inhibited in wounds inoculated with $P$. expansum spores $24 \mathrm{~h}$ after treatment with either IAA or the water control by 1.2 or $19.4 \%$, respectively.

Effects of IAA concentration, timing of application, pathogen spore density, and incubation after pathogen inoculation on blue mold rot development on apple fruit. Because IAA at $20 \mu \mathrm{g} / \mathrm{ml}$ could strongly enhance the biological control of blue mold rot by $C$. laurentii and induce the fruit resistance against the blue mold (Fig. 5), this concentration of IAA was chosen for the following experiment. The results showed that the time between IAA application and pathogen inoculation had a significant effect on disease development. Treatments of IAA at $20 \mu \mathrm{g} / \mathrm{ml}$ had no effect on blue mold rot in apple wounds when applied within $2 \mathrm{~h}$ prior to pathogen spore inoculation onto apple wounds (Fig. 1).

The timing between application of IAA and inoculation of the pathogen at two different spore densities were tested. At a time interval of $24 \mathrm{~h}$, greater inhibition of rot, as determined by lesion diameter, was observed at day 3 to day 5 compared with time intervals of 2 and $12 \mathrm{~h}$. Between the time intervals of 2, 12, and $24 \mathrm{~h}$, differences in the amount of inhibition remained significant at all three observation days when fruit wounds were inoculated with the low pathogen density of $10^{2}$ spores $/ \mathrm{ml}$ (at least $P<0.05$, Table 2). Regardless of pathogen inoculum density, effective reduction in lesion diameter was significantly different when comparing time intervals of $12 \mathrm{~h}$ with $2 \mathrm{~h}$ between application of IAA and inoculation with $P$. expansum, but the level of effectiveness at $12 \mathrm{~h}$ was much lower compared with the $24 \mathrm{~h}$ time interval $(P<0.05)$. In addition, a significant difference in inhibition was observed between inoculum densities of $10^{2}$ and $10^{6}$ spores $/ \mathrm{ml}$, but only on day 4 and only for timing of application of $24 \mathrm{~h}$.

Regression analysis (Fig. 6) showed the relationship of average lesion diameter for IAA treatments at different concentrations $(y)$ and the incubation time after pathogen inoculation $(x)$, which was described by the following equation: at $2 \mu \mathrm{g} / \mathrm{ml}, y=-22.131 x+$ 104.08, $\gamma^{2}=0.994$ (Pearson correlation coefficient $=-0.975, P=$ 0.000 ); at $20 \mu \mathrm{g} / \mathrm{ml}, y=-24.3 x+127.54, \gamma^{2}=0.9883$ (Pearson correlation coefficient $=-0.984, P=0.000)$; and at $200 \mu \mathrm{g} / \mathrm{ml}, y=$ $-2.0631 x+11.655, \gamma^{2}=0.9853$ (Pearson correlation coefficient $=$ $-0.421, P=0.152)$. These results indicated that the efficacy of IAA in inhibiting lesion size was closely correlated with the concentrations of IAA and incubation time.

The slope and $x$-axis position of regression lines for IAA at 200 $\mu \mathrm{g} / \mathrm{ml}$ was nearly linear, while for IAA at 2 or $20 \mu \mathrm{g} / \mathrm{ml}$ were similar in slope and the $x$-axis position for IAA at $20 \mu \mathrm{g} / \mathrm{ml}$ was delayed by the equivalent of a full day (Fig. 6).

In addition, there was a significant positive Pearson correlation coefficient $(0.938, P=0.000)$ of the efficacy of the induced resis-

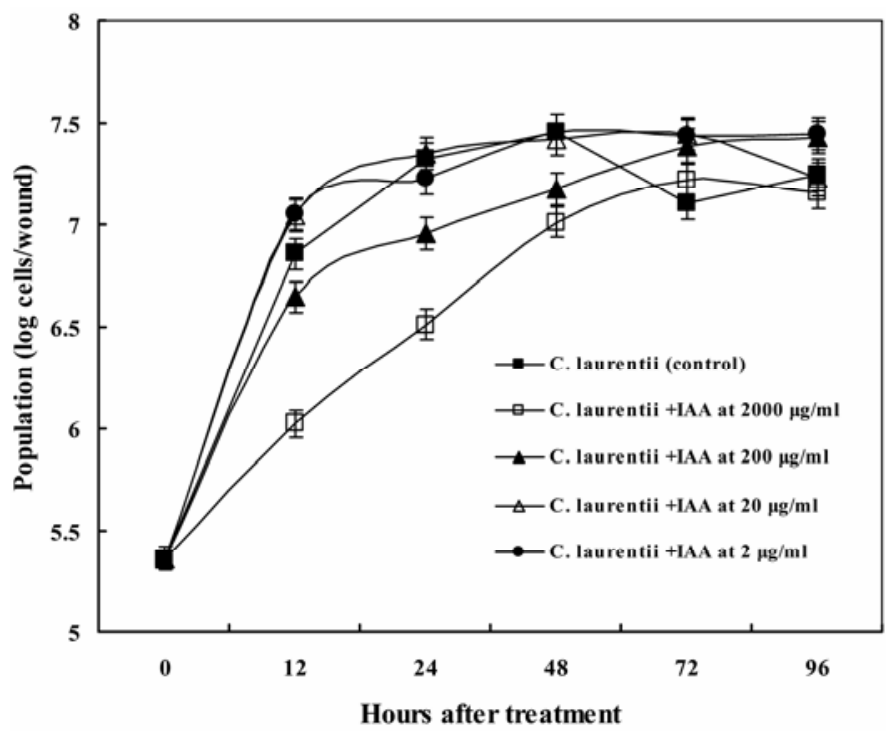

Fig. 3. Effects of indole-3-acetic acid (IAA) on population growth of Cryptococcus laurentii in apple fruit wounds at $20^{\circ} \mathrm{C}$. Each value is the mean of three independent determinations and bars represent the standard errors.

TABLE 1. Effects of indole-3-acetic acid (IAA) on Cryptococcus laurentii and Penicillium expansum in vitro at $28^{\circ} \mathrm{C}^{\mathrm{w}}$

\begin{tabular}{|c|c|c|c|c|c|c|}
\hline \multirow[b]{2}{*}{ IAA $(\mu \mathrm{g} / \mathrm{ml})$} & \multicolumn{2}{|c|}{ C. laurentii in $\mathrm{NYDA}^{\mathrm{x}}(\log$ cells/ml $)$} & \multicolumn{2}{|c|}{ C. laurentii on $\mathrm{NYDA}^{\mathrm{y}}(\mathrm{CFU} / \mathrm{ml})$} & \multicolumn{2}{|c|}{ P. expansum on $\mathrm{PDA}^{\mathrm{z}}(\mathrm{CFU} / \mathrm{ml})$} \\
\hline & & $\begin{array}{c}\text { Reduction } \\
\text { (\% of the control) }\end{array}$ & & $\begin{array}{c}\text { Reduction } \\
\text { (\% of the control) }\end{array}$ & & $\begin{array}{c}\text { Reduction } \\
\text { (\% of the control) }\end{array}$ \\
\hline 0 & $8.94 \pm 0.13 \mathrm{a}$ & & $1,950 \pm 143 a$ & & $2,440 \pm 95 a$ & \\
\hline 0.1 & $8.70 \pm 0.04 b$ & 2.7 & $\ldots$ & & $\ldots$ & \\
\hline 1 & $8.58 \pm 0.04 b$ & 4.0 & $1,590 \pm 69 b$ & 18.5 & $2,550 \pm 179 a$ & 0.0 \\
\hline 10 & $7.48 \pm 0.15 \mathrm{c}$ & 16.3 & $1,550 \pm 48 b$ & 20.5 & $2,690 \pm 155 \mathrm{a}$ & 0.0 \\
\hline 100 & Undetectable* & & $1,100 \pm 61 \mathrm{c}$ & 43.6 & $2,620 \pm 84 a$ & 0.0 \\
\hline 1,000 & Undetectable* & & $83 \pm 45 d$ & 95.7 & $770 \pm 26 b$ & 68.4 \\
\hline
\end{tabular}

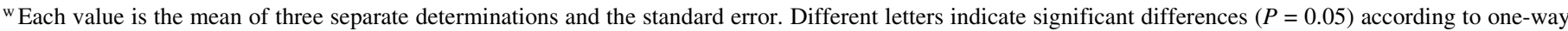
analysis of Duncan's multiple range test.

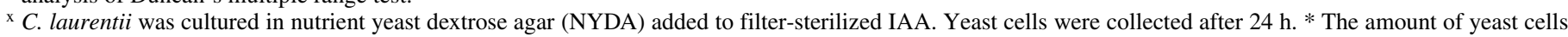
was lower than the detectable threshold $\left(5 \times 10^{4}\right.$ cells $\left./ \mathrm{ml}\right)$ determined by a hemacytometer.

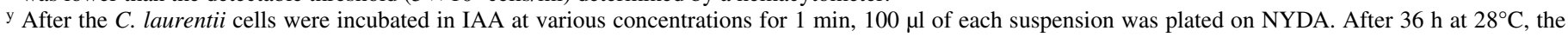
colonies per plate were counted and converted to $\mathrm{CFU} / \mathrm{ml}$.

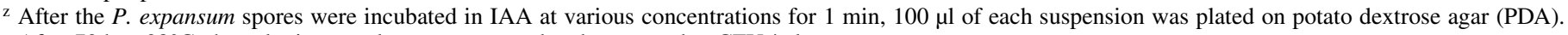
After $72 \mathrm{~h}$ at $28^{\circ} \mathrm{C}$, the colonies per plate were counted and converted to $\mathrm{CFU} / \mathrm{ml}$. 


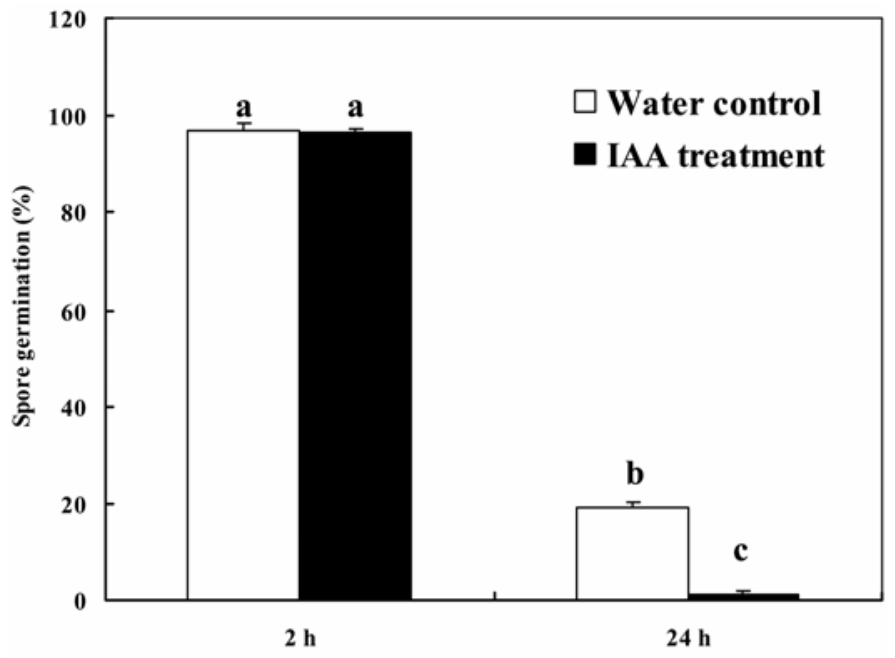

Time between IAA treatment and pathogen inoculation

Fig. 4. In vivo detection of spore germination of Penicillium expansum from apples treated with indole-3-acetic acid (IAA). Each value is the mean of three independent determinations of the percentage of spore germination and the standard error. Values followed by a different letter within a column show significant inhibition of spore germination $(P<0.00001)$ according to Duncan's multiple range test.

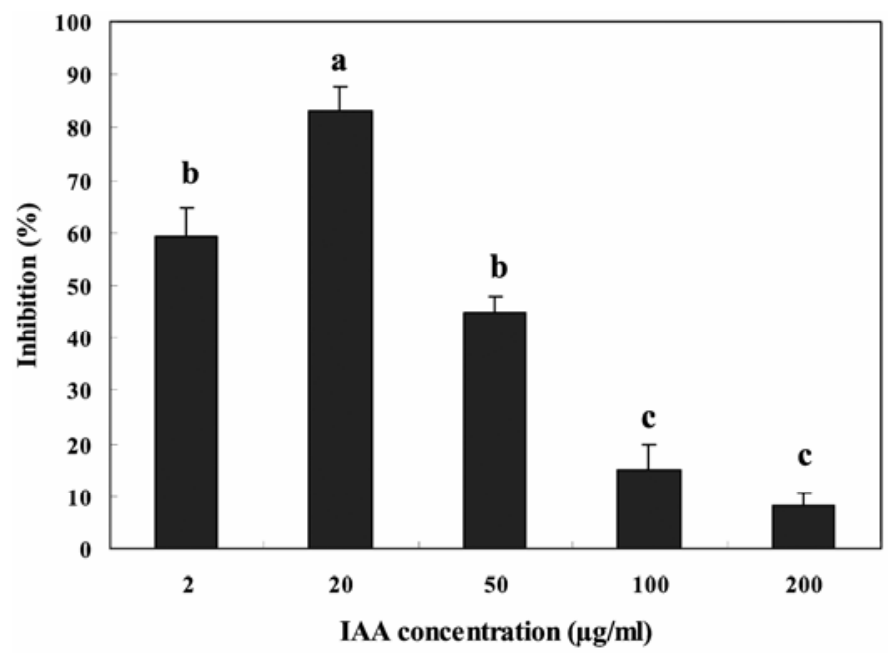

Fig. 5. Effects of indole-3-acetic acid (IAA) concentration on reduction of blue mold rot in apple fruit wounds at $20^{\circ} \mathrm{C}$. Apple fruit were wounded and treated with IAA at 2, 20,50,100, and $200 \mu \mathrm{g} / \mathrm{ml} 24 \mathrm{~h}$ prior to inoculation with Penicillium expansum. Data were recorded at a further 4 days after inoculation. The percent inhibition (\%) of the lesion diameter of infected wounds was calculated by comparison with the control as described in the text. Each value is the mean of three separate determinations and bars represent the standard errors. Different letters indicate significant differences $(P=0.01)$ according to Duncan's multiple range test. tance by IAA at 2,20 , and $200 \mu \mathrm{g} / \mathrm{ml}$ and efficacy of $C$. laurentii with IAA at the comparable concentration and the comparable incubation time (IAA alone on day 3 to day 6 ; $C$. laurentii combined with IAA on day 5 to day 8).

Application of IAA at a concentration of $20 \mu \mathrm{g} / \mathrm{ml}$ also significantly reduced rot incidence on intact apple fruit, especially as time between application and pathogen inoculation was $48 \mathrm{~h}$, whereas its effective was remarkably decreased when the time interval was reduced to $24 \mathrm{~h}$, or increased to $120 \mathrm{~h}$ (Fig. 7).

However, it should be noted that the induced resistance by IAA was most effective in inhibiting the early stages of infection (Table 2; Fig. 6) but decreased as incubation time after pathogen inoculation went by.

\section{DISCUSSION}

The results from this study demonstrated that the combination of IAA at $20 \mu \mathrm{g} / \mathrm{ml}$ with the biocontrol yeast $C$. laurentii was a much more effective means to control blue mold rot in apple fruit wounds than the application of $C$. laurentii alone. Similar control effects of postharvest blue and gray mold rot using a combination of $C$. laurentii and IAA was observed in pear fruit (36). Since IAA has no residue problem when used as plant regulator on all food commodities after harvest (31), this combination of $C$. laurentii with IAA might be considered to be a safe and effective means for controlling $P$. expansum infection in harvested fruit.

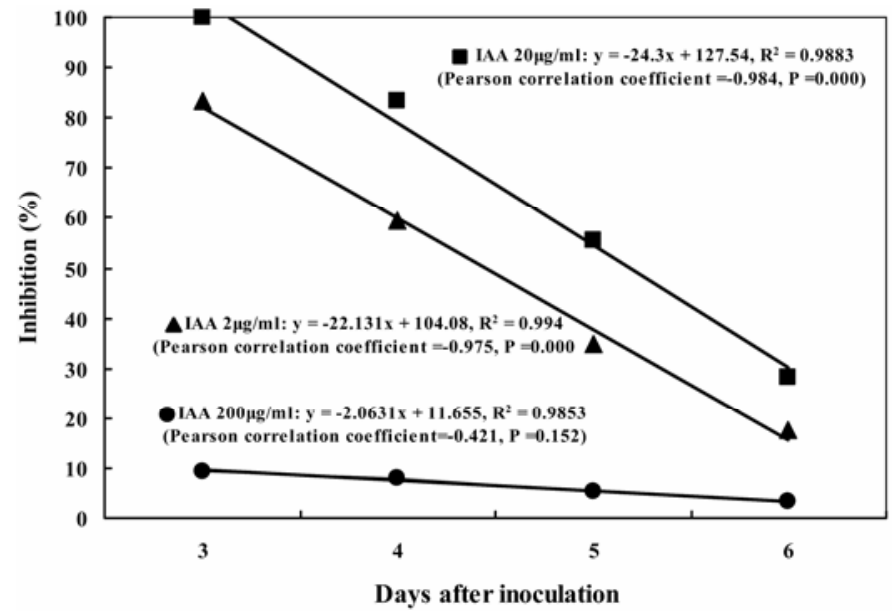

Fig. 6. Effects of indole-3-acetic acid (IAA) at different concentrations on induction of diseases resistance against blue mold rot in apple fruit wounds over time at $20^{\circ} \mathrm{C}$. Apple fruit were wounded and treated with IAA at 2, 20, and $200 \mu \mathrm{g} / \mathrm{ml} 24 \mathrm{~h}$ priot to inoculation with Penicillium expansum. The percent inhibition (\%) of the lesion diameter of infected wounds was calculated by comparison with the control as described in the text. Each value is the mean of three separate determinations.

TABLE 2. Effects of timing between indole-3-acetic acid (IAA) application and pathogen spore density on blue mold rot in apple fruit wounds at $20^{\circ} \mathrm{C}^{\mathrm{z}}$

\begin{tabular}{|c|c|c|c|c|}
\hline \multirow[b]{2}{*}{ Timing application } & \multirow[b]{2}{*}{ Inoculum density } & \multicolumn{3}{|c|}{ Inhibition of blue mold after inoculation (\%) } \\
\hline & & D3* & $\mathrm{D} 4 * *$ & $\mathrm{D} 5 * *$ \\
\hline $24 \mathrm{~h}$ & $10^{6}$ spores $/ \mathrm{ml}$ & $83.1 \pm 4.6 \mathrm{a}$ & $28.2 \pm 5.4 \mathrm{~b}$ & $22.3 \pm 3.2 \mathrm{ab}$ \\
\hline $12 \mathrm{~h}$ & $10^{2}$ spores $/ \mathrm{ml}$ & $12.6 \pm 3.1 \mathrm{~b}$ & $10.6 \pm 2.1 \mathrm{c}$ & $15.6 \pm 5.5 \mathrm{bc}$ \\
\hline \multirow[t]{2}{*}{$2 \mathrm{~h}$} & $10^{6}$ spores $/ \mathrm{ml}$ & $0 \pm 0 \mathrm{c}$ & $0 \pm 0 \mathrm{~d}$ & $0 \pm 0 \mathrm{~d}$ \\
\hline & $10^{2}$ spores $/ \mathrm{ml}$ & $0 \pm 0 \mathrm{c}$ & $0 \pm 0 \mathrm{~d}$ & $0 \pm 0 \mathrm{~d}$ \\
\hline
\end{tabular}

${ }^{\mathrm{z}}$ Apple fruit were wounded and treated with $30 \mu \mathrm{l}$ of filter-sterilized IAA at $20 \mu \mathrm{g} / \mathrm{ml}$ or with $30 \mu \mathrm{l}$ of distilled water as the control at 2,12 , or $24 \mathrm{~h}$ before inoculation. The treatment with distilled water and inoculated with Penicillium expansum served as the control at each time point. The inhibition data (percent reduction in lesion diameter) were calculated compared with the control, which was described in the text. The rot symptoms were observed 3 days (D3), 4 days (D4), and 5 days (D5) after inoculation, respectively. Each value is the mean of three independent determinations and the standard error. Values followed by a different letter show significant inhibition $(*=0.000001$ level; $* *=0.05$ level $)$ according to Duncan's multiple range test. 
Results from in vitro growth experiments showed that IAA at concentrations between 0.1 and $1,000 \mu \mathrm{g} / \mathrm{ml}$ could inhibit the yeast $C$. laurentii on NYDA, whereas it produced the inhibition of the fungus $P$. expansum only when the IAA concentration was at $1,000 \mu \mathrm{g} / \mathrm{ml}$ on PDA. Inhibitory effects of IAA were also observed with the yeast $S$. cerevisiae, and the fungal pathogen $U$. maydis and the oomycete $P$. infestans under different in vitro conditions $(22,25)$. However, in apple fruit wounds, inhibition by IAA on the growth of $C$. laurentii was observed only when the concentration of IAA was increased to $200 \mu \mathrm{g} / \mathrm{ml}$ or above, whereas IAA at concentrations ranging from 2 to $2,000 \mu \mathrm{g} / \mathrm{ml}$ had no direct antifungal activity against blue mold infection.

Previously, we also observed that IAA had no direct antifungal activity against $P$. expansum and $B$. cinerea in pear fruit (36). These data suggested in vitro results did not accurately represent in vivo situations (27) and IAA had little direct fungicidal activity in vivo. However, the results from the present study revealed that IAA could exhibit a strong inhibition of the blue mold rot when the time interval between the IAA treatment and the $P$. expansum inoculation was increased to $24 \mathrm{~h}$ in the wounds or to $48 \mathrm{~h}$ in the intact fruit. Similar results were obtained with $P$. infestans on the detached potato leaves in which a reduction in the late blight infection was observed when the leaves were incubated in a solution of IAA for $24 \mathrm{~h}$ and then inoculated with P. infestans (22). Accordingly, we suggested that IAA could induce host-mediated resistance against fungal pathogens, but requires a sufficient induction time to be effective. It has been demonstrated that fruit resistance induced by various elicitors, such as $\beta$-aminobutyric acid, chitosan, harpin, postharvest biocontrol yeasts (Candida oleophila and C. saitoana), salicylic acid, UV irradiation, and sodium silicate, usually develops in one or a few days $(5,9$, 12,13,23,34).

Induced plant resistance triggered by various elicitors that do not act directly against pathogens is an attractive means of disease control because of their potential to be far less toxic than fungicides (32). However, it is worth noting that success of inducing plant resistance as a disease control method relies on rapid development and at adequate intensity upon challenge by a

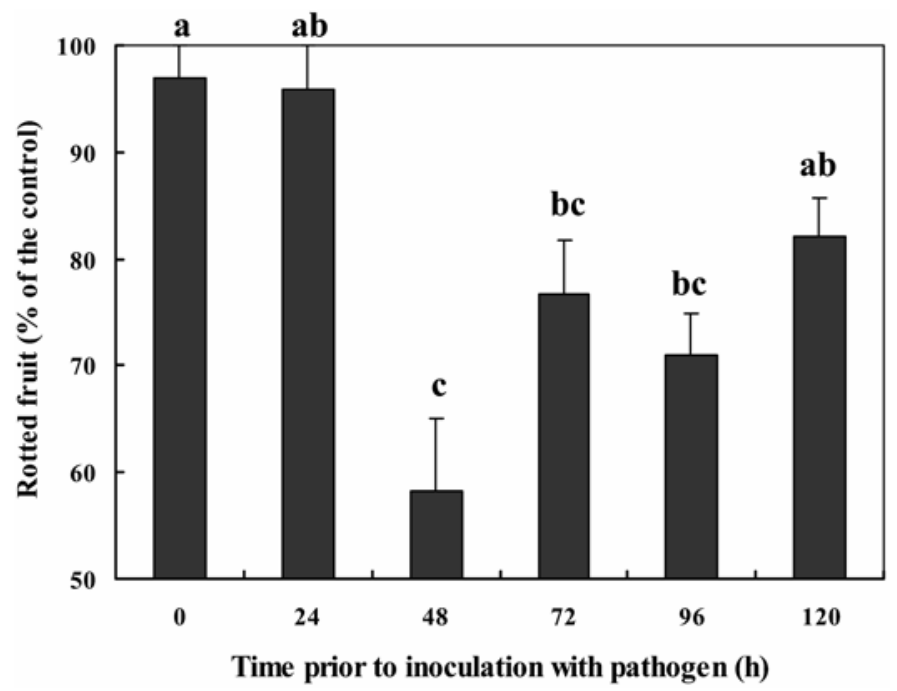

Fig. 7. Effects of indole-3-acetic acid (IAA) on incidence of blue mold rot in intact apple fruit at $20^{\circ} \mathrm{C}$. The intact fruit samples were dipped in IAA $(20 \mu \mathrm{g} / \mathrm{ml})$ solution for $20 \mathrm{~min}$, or in the distilled water for $20 \mathrm{~min}$ as the control. After $0,24,48,72,96$, and $120 \mathrm{~h}$, one of six sets of the treated fruit was wounded and inoculated with $30 \mu \mathrm{l}$ of Penicillium expansum spore suspension $\left(1 \times 10^{4}\right.$ spores $\left./ \mathrm{ml}\right)$. The disease incidence was recorded on every fourth day after inoculation. The percentage of the rotted wounds (\% of control) was calculated as described in the text. Each value is the mean of three separate determinations and bars represent the standard error. Different letters indicate significant differences $(P=0.05)$ according to Duncan's multiple range test. Bars represent standard errors of three replicate. pathogen $(7,30)$, because necrotrophic pathogens can start the infection process immediately after their spores land on wound sites (15). Consequently, the pathogen is capable of killing host cells or causing extensive tissue damage at the very early stages of infection (24). Our data showed that the spores of $P$. expansum germinated quickly within $12 \mathrm{~h}$ in apple fruit wounds, which was consistent to that reported by Amiri et al. (2) who also found that emergence of the germ tube of $P$. expansum was observed in 12 to $24 \mathrm{~h}$ of inoculation on apple wounds followed by the formation of the conidiophore and sporulation. Hence, we deduce here that the time lag between IAA treatment and induced resistance might be the key reason for the failure of IAA alone to reduce the blue mold infection directly; the time needed for the IAA-induced resistance in apple fruit ( 24 to $48 \mathrm{~h}$ ) was much longer than for the spore germination of $P$. expansum in vivo $(12 \mathrm{~h})$.

In our tests, the biocontrol yeast $C$. laurentii proliferated rapidly within the first 12 to $24 \mathrm{~h}$ of incubation in apple fruit wounds, which was in agreement with that reported by Roberts (26). This suggested that the biocontrol yeast could rapidly colonize apple wounds and preemptively utilize available nutrients needed for pathogen colonization $(14,16,26)$. Furthermore, we speculate that in combination with IAA, the biocontrol yeast C. laurentii would be the first and primary line of defense against the mold infection, while IAA could be considered a second line of defense that reinforces the biocontrol efficacy of $C$. laurentii, resulting in an integrated, more effective biological means to reduce the postharvest decay than either method alone.

Our data showed that $C$. laurentii alone or with IAA had most effective results in inhibiting the early stages of infection (within 5 days), whereas their efficacy decreased as the time of incubation went by and could not provide complete protection from the mold infection, although $C$. laurentii with IAA could delay the mold rot development by another 1 to 2 days under the designed experiment conditions compared with the $C$. laurentii alone. These results imply that treatments involving $C$. laurentii and IAA primarily produced fungistatic, but not fungicidal, effects on the mold growth. Therefore, the effectiveness and consistency of this combined control means of using $C$. laurentii and IAA need to be further improved for practical purposes.

\section{ACKNOWLEDGMENTS}

This research was supported by grants from the National High-Tech Research and Development Program of China (863 Program 2006AA10Z348), the National Natural Science Foundation of China (30771514), and the Zhejiang Provincial Natural Science Foundation of China (Z307440)

\section{LITERATURE CITED}

1. Amiri, A., and Bompeix, G. 2005. Diversity and population dynamics of Penicillium spp. on apples in pre- and postharvest environments: consequences for decay development. Plant Pathol. 54:74-81.

2. Amiri, A., Cholodowski, D., and Bompeix, G. 2005. Adhesion and germination of waterborne and airborne conidia of Penicillium expansum to apple and inert surfaces. Physiol. Mol. Plant Pathol. 67:40-48.

3. Baldwin, E. A. 2003. Coatings and other supplemental treatments to maintain vegetable quality. Pages 413-435 in: Postharvest Physiology and Pathology of Vegetables. Marcel Dekker, New York.

4. Berleth, T., Krogan, N. T., and Scarpella, E. 2004. Auxin signals-turning genes on and turning cells around. Curr. Opin. Plant Biol. 7:553-563.

5. Bi, Y., Tian, S. P., Guo, Y. R., Ge, Y. H., and Qin, G. Z. 2006. Sodium silicate reduces postharvest decay on Hami melons: Induced resistance and fungistatic effects. Plant Dis. 90:279-283.

6. Cohen, J. D. 1996. In vitro tomato fruit cultures demonstrate a role for indole-3-acetic acid in regulating fruit ripening. J. Am. Soc. Hort. Sci. 121:520-524.

7. Conrath, U., Beckers, G. J. M., Flors, V., García-Agustín, P., Jakab, G., Mauch, F., Newman, M., Pieters, C. M. J., Poinssot, B., Pozo, M. J., Pugin, A., Schaffrath, U., Ton, J., Wendehenne, D., Zimmerli, L., and Mauch-Mani, B. 2006. Priming: Getting ready for battle. Mol. PlantMicrobe Interact. 19:1062-1071. 
8. Conway, W. S., Leverentz, B., Janisiewicz, W. J., Saftner, R. A., and Camp, M. J. 2005. Improving biocontrol using antagonist mixtures with heat and/or sodium bicarbonate to control postharvest decay of apple fruit. Postharv. Biol. Technol. 36:235-244.

9. de Capdeville, G., Beer, S. V., Watkins, C. B., Wilson, C. L., Tedeschi, L. O., and Aist, J. R. 2003. Pre- and post-harvest harpin treatments of apples induce resistance to blue mold. Plant Dis. 87:39-44.

10. de Capdeville, G., Wilson, C. L., Beer, S. V., and Aist, J. R. 2002. Alternative disease control agents induce resistance to blue mold in harvested 'Red Delicious' apple fruit. Phytopathology 92:900-908.

11. Droby, S. 2006. Improving quality and safety of fresh fruits and vegetables after harvest by the use of biocontrol agents and natural materials. Acta Hortic. 709:45-51.

12. Droby, S., Vinokur, V., Weiss, B., Cohen, L., Daus, A., Goldschmidt, E. E., and Porat, R. 2002. Induction of resistance to Penicillium digitatum in grapefruit by the yeast biocontrol agent Candida oleophila. Phytopathology 92:393-399.

13. El Ghaouth, A., Wilson, C. L., and Wisniewski, M. 2003. Control of postharvest decay of apple fruit with Candida saitoana and induction of defense responses. Phytopathology 93:344-348.

14. El Ghaouth, A., Wilson, C. L., Wisniewski, M., Droby, S., Smilanick, J. L., and Korsten, L. 2002. Biological control of postharvest diseases of citrus fruits. Pages 289-312 in: Biological Control of Crop Diseases. S. Gnanamanickam, ed. Marcel Dekker, New York.

15. Glazebrool, J. 2005. Contrasting mechanisms of defense against biotrophic and necrophic pathogens. Annu. Rev. Phytopathol. 43:205227.

16. Janisiewicz, W. J., and Korsten, L. 2002. Biological control of postharvest diseases of fruits. Annu. Rev. Phytopathol. 40:411-441.

17. Lima, G., De Curtis, F., Piedimonte, D., Spina, A. M., and De Cicco, V. 2006. Integration of biocontrol yeast and thiabendazole protects stored apples from fungicide sensitive and resistant isolates of Botrytis cinerea. Postharv. Biol. Technol. 40:301-307.

18. Lima, G., Spina, A. M., Castoria, R., De Curtis, F., and De Cicco, V. 2005. Integration of Biocontrol agents and food-grade additives for enhancing protection of stored apples from Penicillium expansum. J. Food Prot. 68:2100-2106.

19. Ludford, P. M. 2003. Hormonal changes during postharvest. Pages 31-77 in: Postharvest Physiology and Pathology of Vegetables. Marcel Dekker, New York.

20. Mayda, E., Marqués, C., Conejero, V., and Vera, P. 2000. Expression of a pathogen-induced gene can be mimicked by auxin insensitivity. Mol. Plant-Microbe Interact. 13:23-31.

21. Mayda, E., Mauch-Mani, B., and Vera, P. 2000. Arabidopsis dth9 mutation identifies a gene involved in regulating disease susceptibility without affecting salicylic acid-dependent responses. Plant Cell 12:2119-2128.

22. Noël, G. M. A. M., Madrid, E. A., Bottini, R., and Lamattina, L. 2001. Indole acetic acid attenuates disease severity in potato-Phytophthora infestans interaction and inhibits the pathogen growth in vitro. Plant Physiol. Biochem. 39:815-823.

23. Porat, R., Vinokur, V., Weiss, B., Cohen, L., Daus, A., Goldschmidt, E. E., and Droby, S. 2003. Induction of resistance to Penicillium digitatum in grapefruit by $\beta$-aminobutyric acid. Eur. J. Plant Pathol. 109:901-907.

24. Prusky, D., and Lichter, A. 2007. Activation of quiescent infections by postharvest pathogens during transition from the biotrophic to the necrotrophic stage. FEMS Microbiol. Lett. 268:1-8.

25. Prusty, R., Grisafi, P., and Fink, G. R. 2004. The plant hormone indoleacetic acid induces invasive growth in Saccharomyces cerevisiae. Proc. Natl. Acad. Sci. USA 101:4153-4157.

26. Roberts, R. G. 1990. Postharvest biological control of gray mold of apples by Cryptococcus laurentii. Phytopathology 80:526-530.

27. Rotem, J., Cohen, Y., and Bashi, E. 1978. Host and environmental influences on sporulation in vivo. Annu. Rev. Phytopathol. 16:83-101.

28. Sholberg, P. L., and Conway, W. S. 2004. Postharvest Pathology. In: Agriculture Handbook Number 66: The Commercial Storage of Fruits, Vegetables, and Florist and Nursery Stocks. K. C. Gross, C. Y. Wang, and M. Saltveit, eds. Published online by the U.S. Department of Agriculture (USDA), the Agricultural Research Service (ARS), Washington, D.C.

29. Slininger, P. J., Burkhead, K. D., and Schisler, D. A. 2004. Antifungal and sprout regulatory bioactivities of phenylacetic acid, indole-3-acetic acid, and tyrosol isolated from the potato dry rot suppressive bacterium Enterobacter cloacae S11:T:07. J. Indust. Microbiol. Biotechnol. 31:517524.

30. Ton, J., Jakab, G., Toquin, V., Flors, V., Iavicoli, A., Maeder, M. N., Mé traux, J., and Mauch-Mania, B. 2005. Dissecting the $\beta$-aminobutyric acidinduced priming phenomenon in Arabidopsis. Plant Cell 17:987-999.

31. U.S. Environmental Protection Agency. 1998. Certain plant regulators, cytokinins, auxins, gibberellins, ethylene, and pelargonic acid; tolerance exemptions. Published online by the U.S. Environmental Protection Agency (EPA) http://www.epa.gov/fedrgstr/EPA-PEST/1998/October/ Day-23/p28360.htm.

32. Walters, D., Walsh, D., Newton, A., and Lyon, G. 2005. Induced resistance for plant disease control: Maximizing the efficacy of resistance elicitors. Phytopathology 95:1368-1373.

33. Yu, T., Li, H., and Zheng, X. 2007. Synergistic effect of chitosan and Cryptococcus laurentii on inhibition of Penicillium expansum infections. Int. J. Food Microbiol. 114:261-266.

34. Yu, T., and Zheng, X. 2006. Salicylic acid enhances biocontrol efficacy of the antagonist Cryptococcus laurentii in apple fruit. J. Plant Growth Reg. 25:166-174.

35. Yu, T., and Zheng, X. 2007. An integrated strategy to control postharvest blue and grey mould rots of apple fruit by combining biocontrol yeast with gibberellic acid. Int. J. Food Sci. Technol. 42:977-984.

36. Yu, T., and Zheng, X. 2007. Indole-3-acetic acid enhances the biocontrol of Penicillium expansum and Botrytis cinerea on pear fruit by Cryptococcus laurentii. FEMS Yeast Res. 7:459-464. 